\title{
Effects of trichostatin A on HIF-1 $\alpha$ and VEGF expression in human tongue squamous cell carcinoma cells in vitro
}

\author{
FEI-WU KANG, LIN QUE, MIN WU, ZUO-LIN WANG and JING SUN \\ Department of Oral and Maxillofacial Surgery, Hospital of Stomatology, Tongji University, Shanghai 200072, P.R. China
}

Received December 28, 2011; Accepted February 17, 2012

DOI: $10.3892 / o r .2012 .1784$

\begin{abstract}
Hypoxia is an essential feature of the microenvironment of solid tumors, which regulates a variety of transcription factors including hypoxia-inducible factor- $1 \alpha$ (HIF-1 $\alpha)$. HIF-1 $\alpha$ overexpression enhances tumor angiogenesis via upregulation of vascular endothelial growth factor (VEGF) and some other hypoxia-inducible angiogenic factors, which lead to a more aggressive tumor phenotype, tumor metastasis and resistance to radiation and chemotherapy. In this study, we found that a histone deacetylase (HDAC) inhibitor, trichostatin A (TSA), inhibited cell proliferation and invasion, blocked the cell cycle, and induced cell apoptosis in a dose- and time-dependent manner in the human tongue squamous cell carcinoma (TSCC) SCC- 6 cell line in vitro. Furthermore, TSA reduced both basal levels and hypoxia-induced HIF- $1 \alpha$ protein accumulation but not HIF-1 $\alpha$ mRNA levels, and both protein and mRNA levels of VEGF expression. These results showed that TSA had a potent anticancer activity on TSCC cells, suggesting that TSA could be a promising drug targeting tumor angiogenesis via inhibition of HIF-1 $\alpha$ and VEGF expression in the development of an effective chemopreventive and anticancer agent on human TSCCs.
\end{abstract}

\section{Introduction}

Oxygen is essential for the cells and tissues in maintaining their function and integrity. Lack of oxygen often occurs in the central area of solid tumors as well as in embryonic development (1-3), which leads to a more aggressive tumor phenotypes, characterized by abnormal angiogenesis, invasion, metastasis and resistance to radiation and chemotherapy $(4,5)$. Angiogenesis not only has strong implications in homeostasis, but also plays an integral role in solid tumor survival, progression and metastasis (6). Hypoxia regulates a number of different transcription

Correspondence to: Professor Zuo Lin Wang, Department of Oral and Maxillofacial Surgery, Hospital of Stomatology, Tongji University, Shanghai 200072, P.R. China

E-mail: zuolin@mail.tongji.edu.cn

Key words: tongue squamous cell carcinoma, hypoxia-inducible factor-1 $\alpha$, trichostatin A, angiogenesis factors that may be vital in hypoxia-induced cell responses including hypoxia-inducible factor (HIF-1), which regulates hypoxia-inducible angiogenic factors such as vascular endothelial growth factor(VEGF) and the glycolytic enzymesery $(1,7)$. VEGF is a survival factor in endothelial and tumor cells via VEGF receptors which are upregulated by hypoxia (8-11). This stimulates the cell to adapt to hypoxic microenvironment. Thus, enhancement of angiogenesis by hypoxia is a prerequisite for progressive growth and metastasis of solid tumors (12).

Hypoxia-inducible factor-1 (HIF-1) is a heterodimeric transcription factor consisting of two subunits: HIF-1 $\alpha$ and HIF-1 $\beta$. HIF- $1 \alpha$ is ubiquitously found in human tissues undergoing rapid ubiquitination and proteasomal degradation under normoxic conditions and stabilizes under hypoxic conditions. The expression of HIF-1 $\alpha$ is strictly regulated by low oxygen tension. HIF-1 $\alpha$ is also responsible for cell adaptation to both normoxic and hypoxic conditions. The mRNA and protein levels of HIF-1 $\beta$, also called aryl hydrocarbon receptor nuclear translocator (ARNT) (13) express constantly and are not connected with oxygen tension (14). Under normoxic conditions, the oxygen-dependent degradation domain (ODDD) of HIF-1 $\alpha$ interacts with the von Hippel-Lindau protein (pVHL) ubiquitin E3 ligase complex. Such HIF-1 $\alpha$ /von Hippel-Lindau protein interaction requires oxygen and iron-dependent hydroxylation of proline residues (Pro402 and Pro564) in HIF-1 $\alpha$ protein and inhibits the binding of transcriptional co-activators p300 and CBP of HIF-1 $\alpha$ protein via the $26 \mathrm{~S}$ proteasome (15-20).

Under hypoxic conditions, HIF-1 $\alpha$ protein accumulates and stabilizes by remaining unhydroxylated, and translocates into the nucleus where it dimerizes with HIF-1 $\beta$ and forms an active complex (21). The formed complex initiates transcriptional activation of its target genes via binding to hypoxia response element (HRE) located in the promoter and enhancer regions $(14,22)$. These target genes include erythropoiesis, glycolysis (short-term solution) and angiogenesis (long-term solution) (23) which are essential for adaptation and survival under hypoxic conditions. Previous clinical research reported that overexpression of HIF-1 $\alpha$ has been observed in many human tumors including breast, prostate, brain, lung, tongue and their metastases, and is closely related to tumor angiogenesis, progression and invasion, and resistance to radiation and chemotherapy.

Histone acetyltransferases (HAT) and histone deacetylases (HDAC), which has been considered as transcriptional coactivator and corepressor, play vital roles in regulation of 
gene transcription in many cell types (24). HDAC controls gene expression, transport ubiquitinated protein aggregates, and deacetylate proteins (25-27). Inhibition of HDAC activity generally blocks the cell cycle and may affect cell proliferation and apoptosis $(28,29)$ which is closely connected with tumorigenesis and tumor progression. Some specific HDAC inhibitors have been used to elucidate HDAC function and are suggested as a therapy for some types of cancer (30) which makes HDAC a promising target of anti-cancer activity. We investigated a specific HDAC inhibitor, trichostatin A (TSA), which was reported to be able to block cell cycle at $\mathrm{G}_{1}$ and $\mathrm{G}_{2} / \mathrm{M}$ phase, to inhibit cell proliferation and apoptosis in several tumor cell lines and greatly suppress tumor angiogenesis both in vitro and in vivo (12), had the same effect on human TSCC SCC-6 cells in dose- and time-dependent manner. Furthermore, we demonstrated that TSA inhibited both basal level and hypoxiainduced HIF-1 $\alpha$ protein accumulation and VEGF expression in vitro, providing further evidence that TSA could be a potential anticancer agent on human TSCC by targeting the well-known tumor survival factor HIF-1 $\alpha$ and its downstream gene VEGF, under hypoxia.

\section{Materials and methods}

Reagents and antibodies. Trichostatin A (TSA) was purchased from Sigma (St. Louis, MO, USA) and dissolved at a concentration of $3 \mathrm{mmol} / \mathrm{l}$ in dehydrated alcohol as a stock solution, stored at $-20^{\circ} \mathrm{C}$. Deferoxamine mesylate (DFX) was purchased from Sigma and dissolved in normal saline water at $50 \mathrm{mg} / \mathrm{ml}$ as a stock solution, stored at $-20^{\circ} \mathrm{C}$. Antibodies for HIF- $1 \alpha$ and VEGF were purchased from Santa Cruz Biotechnology (Santa Cruz, CA), stored at $4^{\circ} \mathrm{C}$.

Cell line and cell culture. Human tongue squamous cell carcinoma SCC-6 cell lines were provided by Dr Huang Xin, Beijing Stomatological Hospital, Capital Medical University, Beijing, China. SCC-6 cells were cultured in Dulbecco's modified Eagle's medium/F12 (DMEM/F12=1:1) supplemented with $10 \%$ fetal bovine serum (FBS), $100 \mathrm{U} / \mathrm{ml}$ penicillin, $100 \mathrm{~g} / \mathrm{ml}$ streptomycin. The cultures were incubated at $37^{\circ} \mathrm{C}$ in a humidified atmosphere with $5 \% \mathrm{CO}_{2}$. To simulate hypoxic conditions, cells were treated with the hypoxia mimetic compound DFX (150 $\mu \mathrm{mol} / \mathrm{l})$ instead of cultured at $5 \% \mathrm{CO}_{2}$ with $1 \% \mathrm{O}_{2}$ balanced with $\mathrm{N}_{2}(31,32)$.

Cell proliferation assay. SCC-6 cells were plated in 96-well plates $\left(1 \times 10^{4} /\right.$ well $)$ and treated with different concentrations of TSA $(0,200,400,800,1600,3200 \mathrm{nmol} / \mathrm{l})$ at indicated time intervals $(0,12,24,48 \mathrm{~h})$, and equivalent dehydrated alcohol for control groups. Then cell proliferation was analyzed by MTT colorimetric assay which determines viable cells by detecting conversion of 3-(4, 5-dimethylthiazol-2-yl)-2, 5-diphenyltetrazolium bromide to a purple formazan product (33). The cells were incubated with MTT solution ( $1 \mathrm{mg} / \mathrm{ml}$ in DMEM/F12) for $4 \mathrm{~h}$ at $37^{\circ} \mathrm{C}$ and carefully observed to exclude crystal formation outside the cells. Then the medium was decanted, and dimethyl sulphoxide (DMSO, $150 \mu \mathrm{l} /$ well) added to dissolve the formazan crystals. The number of viable cells correlated with the absorbance (optical density, OD) was measured at $490 \mathrm{~nm}$ by Synergy 2 (BioTek). Cell viability equals the difference of

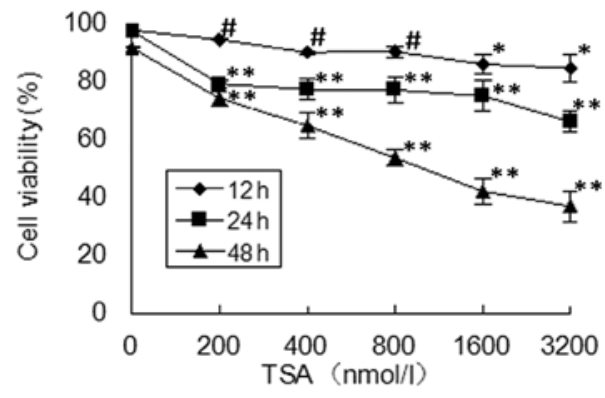

Figure 1. The proliferation inhibition of SCC- 6 cells induced by TSA at the indicated concentrations and time. SCC- 6 cells were cultured under different concentrations of TSA for 12, 24, $48 \mathrm{~h}$, dehydrated alcohol was used as control groups. Cell proliferation was analyzed by MTT colorimetric assay. Absorbance was measured at $490 \mathrm{~nm}$ (bars, $\pm \mathrm{SD},{ }^{*} \mathrm{p}<0.05,{ }^{* *} \mathrm{p}<0.01,{ }^{\#} \mathrm{p}>0.05$ compared to control groups).

$\mathrm{OD}_{\text {experiment }}$ minus $\mathrm{OD}_{\text {blank }}$ divided by the difference of $\mathrm{OD}_{\text {control }}$ minus $\mathrm{OD}_{\text {blank }}$. Each experiment was performed in triplicate and repeated three times.

Cell apoptosis. SCC-6 cells were treated with TSA at the above concentrations for $6,12,24 \mathrm{~h}$. After harvested, the cells were washed twice with PBS and resuspended in binding buffer. Then incubated for 15 min with $5 \mu 1$ of Annexin V-FIITC antibody and $10 \mu 1$ of propidium iodine $(50 \mathrm{mg} / \mathrm{ml})$ at room temperature in the dark according to the manufacturer's protocol prior to FACS analysis. Both early and late stages of apoptotic SCC- 6 cells induced by TSA were detected by a flow cytometer. The presence of apoptotic cells was scored by monitoring the loss of cell membrane phospholipid asymmetry, resulting in the externalization of phosphatidylserine to the outer membrane without loss of membrane integrity (34).

Cell cycle analysis. SCC-6 cells were plated in 6-well plates (1x10\%/well) after reaching $80 \%$ confluence, $12 \mathrm{~h}$ later cells were treated with different concentrations of TSA $(0,50,100,200$, $400,800 \mathrm{nmol} / \mathrm{l})$, then incubated for $24 \mathrm{~h}$. Cells were washed in ice-cold PBS and harvested by trypsinization. Centrifuged at $1000 \mathrm{rpm}$ for $5 \mathrm{~min}$, the supernatant was discarded, propidium iodine $(10 \mu \mathrm{g} / \mathrm{ml})$ was added supplemented with RNaseA (200 $\mu \mathrm{g} / \mathrm{ml})$ to the cells for $30 \mathrm{~min}$ at $37^{\circ} \mathrm{C}$ in the dark, then analysed by a flow cytometer of FACSCanto ${ }^{\mathrm{TM}}$ II (B\&D, USA).

Cell invasion assay. After reaching $80 \%$ confluence, the SCC- 6 cells $\left(1 \times 10^{5}\right)$ were trypsinized and resuspended in the inner chamber of the insert in $200 \mu \mathrm{l}$ of serum-free DMEM/F12 medium. DMEM/F12 medium (500 $\mu \mathrm{l})$ with or without $10 \%$ FBS was added to the lower chamber. Between two chambers was the matrigel gel (B\&D) diluted by serum-free DMEM/ F12 medium and placed on the surface of filtration membrane of the Transwell micropore with an aperture of $8 \mu \mathrm{m}$. TSA at different concentrations $(0,50,100,200,400,800 \mathrm{nmol} / \mathrm{l})$ was added to the inner chamber and equivalent dehydrated alcohol as a control. After incubated at $37^{\circ} \mathrm{C}$ for $24 \mathrm{~h}$, the medium non-invading cells and the extracellular matrigel gel were gently removed by a cotton-tipped swab, and the layer of invasive cells gently washed by PBS. The number of invasive cells that migrated through the gel insert to the lower surface of the membrane were stained and photographed. Results 
A
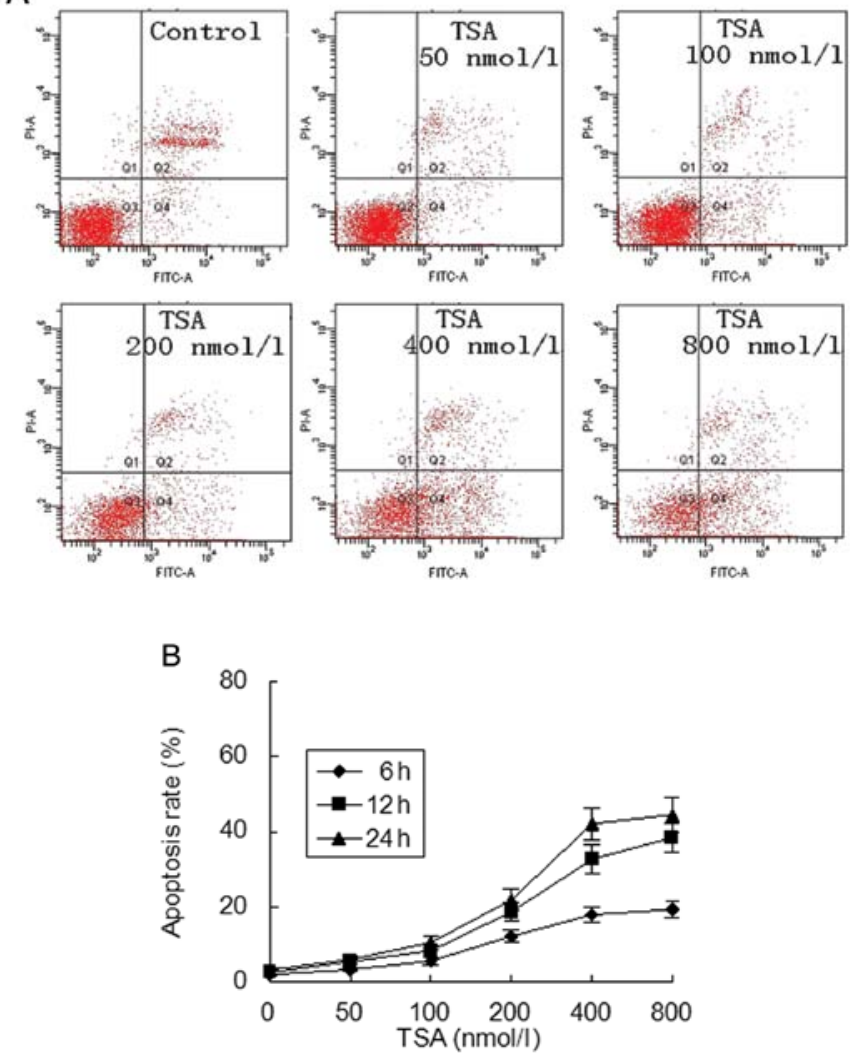

Figure 2. The apoptosis rate of SCC- 6 cells induced by TSA in indicated concentration. (A) SCC- 6 cells treated with TSA in indicated concentration for $24 \mathrm{~h}$. Annexin V-FITC and PI-staining of SCC-6 cells were performed and followed by flow cytometeric analysis. Cells in Q1 quadrant represent cells undergoing necrosis, Q2 quadrant represent late stage of apoptosis, Q3 quadrant represent viable cells and Q4 quadrant represent early stage of apoptosis. (B) TSA increased the SCC- 6 cell apoptosis rate (early stage) in a dose- and time-dependent manner (bars, $\pm \mathrm{SD},{ }^{*} \mathrm{p}<0.05,{ }^{* *} \mathrm{p}<0.01$, compared to control group).

were presented as the mean percentage of the control (control OD at $562 \mathrm{~nm}$ assigned as 100\%). Experiments were done in triplicate and repeated three times.

Real-time reverse transcription polymerase chain reaction (real-time PCR). SCC-6 cells were treated with varied concentrations of DFX or/and TSA at different time periods, respectively. Total RNA was prepared using TRIzol reagent (Invitrogen, USA), and cDNA was synthesized by PrimeScript ${ }^{\circledR}$ RT reagent kit (Takara, China). HIF-1 $\alpha$ and VEGF mRNA expression was evaluated quantitatively by real-time RT-PCR with SYBR ${ }^{\circledR}$ Premix Ex Taq ${ }^{\mathrm{TM}}$ (Takara) and ABI PRISMR 7900HT real-time PCR system (35). The thermocycler conditions were preheating at $95^{\circ} \mathrm{C}$ for $30 \mathrm{sec}$, cycles of $95^{\circ} \mathrm{C}$ for $5 \mathrm{sec}, 60^{\circ} \mathrm{C}$ for $30 \mathrm{sec}$. The relative amount of PCR product was evaluated as threshold cycle (CT value) of the sample divided by that of $\beta$-actin. All experiments were done in triplicate and repeated three times. The primers were synthesized (Sangon, China) and the sequences were: HIF-1 $\alpha$ : forward 5'-GAA CCTGATGCTTTAAACT-3', reverse 5'-CAACTGATCGAA GGAACG-3'; VEGF: forward 5'-TTTCTGCTGTCTTGG GTGCATTGG-3', reverse 5'-TCTGCATGGTGATGTTGGA CTCCT-3'; $\beta$-actin: forward 5'-TGGCACCCAGCACAAT
GAA-3', reverse 5'-CTAAGTCATAGTCCGCCTAGAA GCA-3'.

Western blot analysis. After SCC-6 cells were treated with varied concentrations of DFX or/and TSA at different time periods. Cells were washed with ice-cold PBS twice and treated with buffer $(50 \mathrm{mmol} / \mathrm{l}$ Tris- $\mathrm{HCl}(\mathrm{pH} 7.5), 5 \mathrm{mmol} / \mathrm{l}$ EDTA, $150 \mathrm{mmol} / \mathrm{l} \mathrm{NaCl}, 0.5 \%$ Triton X-100, $10 \mathrm{mmol} / \mathrm{l}$ sodium fluoride, $20 \mathrm{mmol} / \mathrm{l} \mathrm{h}$-mercaptoethanol, $250 \mathrm{Amol} / \mathrm{l}$ sodium orthovanadate, $1 \mathrm{mmol} / \mathrm{l}$ phenylmethylsulfonyl fluoride $50 \mathrm{mmol} / \mathrm{l}$ Tris-HCl (pH 7.5), $5 \mathrm{mmol} / \mathrm{l}$ EDTA, $150 \mathrm{mmol} / \mathrm{l}$ $\mathrm{NaCl}, 0.5 \%$ Triton X-100, $10 \mathrm{mmol} / \mathrm{l}$ sodium fluoride, $20 \mathrm{mmol} / \mathrm{l}$ $\beta$-mercaptoethanol, $250 \mu \mathrm{mol} / 1$ sodium orthovanadate, $1 \mathrm{mmol} / 1$ phenylmethylsulfonyl fluoride). The lysates were centrifuged at $1000 \mathrm{rpm}$ for $10 \mathrm{~min}$ and the supernatants were collected and stored at $-80^{\circ} \mathrm{C}$. Protein concentrations were determined by bicinchoninic acid assay methods (BCA protein assay kit, Thermo, USA). Equivalent amount of protein $(40 \mu \mathrm{g})$ were loaded into 8-12\% SDS-PAGE gel and electroblotted onto protein nitrocellulose membrane (Sigma). The NC membrane was rinsed in PBS-T solution (0.1\% Tween-20 in PBS, pH 7.5) and blocked with 5\% skim milk in PBS-T at room temperature. The membrane was incubated with HIF-1 $\alpha$ (1:200) and VEGF (1:500) antibody overnight at $4^{\circ} \mathrm{C}$ and washed with PBS-T four times every $10 \mathrm{~min}$, then incubated with secondary antibody against rabbit (HIF-1 $\alpha)$ and mouse (VEGF) (1:2000) at room temperature for $1 \mathrm{~h}$ and washed with PBS-T four times every 10 min $(36,37)$. The signals were visualized by enhanced chemiluminescence using Odyssey chemiluminescence system (LI-COR, USA).

Statistical analysis. Statistical analysis was performed using the SPSS 14.0 software package. Data were expressed as the means \pm SD. A paired Student's test was used for statistical analysis, with significant differences determined as $\mathrm{p}<0.05$.

\section{Results}

TSA inhibited cell proliferation of SCC- 6 cells. SCC-6 cells were treated with different concentrations of TSA for 12, 24, $48 \mathrm{~h}$, dehydrated alcohol was used as control group. Within $12 \mathrm{~h}$, the proliferation of SCC- 6 cells treated with 200, 400, $800 \mathrm{nmol} / 1$ of TSA was not inhibited significantly compared to the control group $(94.48 \pm 0.21 \%, 90.10 \pm 0.51 \%, 90.28 \pm 2.01 \%$ vs. $99.12 \pm 0.11 \%, \mathrm{p}>0.05)$ until the concentration of TSA reached $1600,3200 \mathrm{nmol} / 1(86.06 \pm 3.43 \%, 84.64 \pm 4.87 \%$ vs. $99.12 \pm 0.11 \%, \mathrm{p}<0.05)$. At 24 and $48 \mathrm{~h}$, TSA significantly inhibited the proliferation of SCC- 6 cells compared to control groups even at $200 \mathrm{nmol} / 1(0.7927 \pm 0.0131$ vs. $0.9901 \pm 0.0013$, $0.7427 \pm 0.0257$ vs. $0.9166 \pm 0.0021, \mathrm{P}<0.01$ ) (Fig. 1). These results suggest that TSA inhibited the proliferation of SCC-6 cells in a dose- and time-dependent manner.

Apoptosis of SCC-6 cells induced by TSA. After SCC- 6 cells were treated with different concentrations of TSA for 6,12 , $24 \mathrm{~h}$, apoptosis rate of SCC-6 cells increased significantly in a concentration-dependent manner, compared to control groups, especially at $24 \mathrm{~h}(6.17 \pm 0.92 \%, 10.64 \pm 1.87 \%, 21.92 \pm 2.73 \%$ vs. $3.31 \pm 0.45 \%, \mathrm{p}<0.05 ; 42.15 \pm 4.17 \%, 44.56 \pm 4.66 \%$ vs. $3.31 \pm 0.45 \%, p<0.01$ ) (Fig. 2), indicating that TSA induced cell apoptosis of SCC- 6 cells in a dose- and time-dependent 


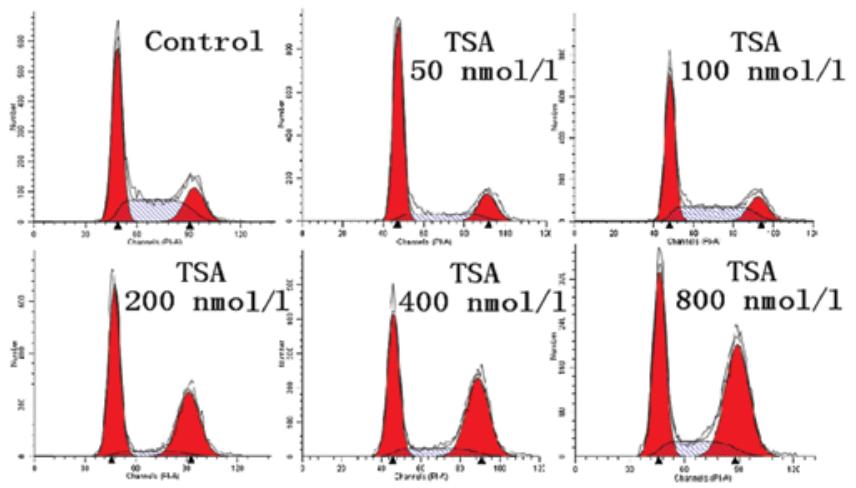

Figure 3. The cell cycle changes of SCC-6 cells treated with TSA at indicated concentrations for $24 \mathrm{~h}$. The cell cycle was analysed by flow cytometry using propidium iodide for DNA staining. Percentage of cell numbers decreased at $\mathrm{G}_{0} / \mathrm{G}_{1}$ phase and increased at $\mathrm{S}$ and $\mathrm{G}_{2} / \mathrm{M}$ phase.

manner, and this effect might be related to the cell cycle blockade at $\mathrm{S}$ and $\mathrm{G}_{2} / \mathrm{M}$ phase.

Effect of TSA on cell cycle of SCC-6 Cells. SCC-6 cells were treated with different concentrations of TSA for $24 \mathrm{~h}$, then DNA staining by propidium iodide was done for discrimination of cells at $G_{0} / G_{1}$ phase or $S$ and $G_{2} / M$ phase by FACS. With the concentrations of TSA increased, the cells at $\mathrm{G}_{0} / \mathrm{G}_{1}$ phase decreased significantly $(50.06 \pm 4.27 \%, 47.68 \pm 5.24 \%$, $53.53 \pm 6.27 \%, 42.19 \pm 5.39 \%, 39.38 \pm 4.86 \%$ vs. $65.26 \pm 4.47 \%$, $\mathrm{p}<0.05)$. Consequently, the cells at $\mathrm{G}_{2} / \mathrm{M}$ and $\mathrm{S}$ phase significantly increased, respectively $(15.63 \pm 1.78 \%, 17.76 \pm 2.01 \%$, $38.57 \pm 4.24 \%, 44.33 \pm 5.19 \%, 45.16 \pm 4.83 \%$ vs. $17.09 \pm 1.28 \%$, $\mathrm{p}<0.05)(34.31 \pm 3.97 \%, 34.64 \pm 4.26 \%, 7.90 \pm 0.97 \%, 13.48 \pm 1.47 \%$, $15.46 \pm 1.84 \%$ vs. $17.66 \pm 1.24 \%, \mathrm{p}<0.05$ ) (Fig. 3). Thus, TSA blocked the cell cycle of SCC- 6 cells at $\mathrm{S}$ and $\mathrm{G}_{2} / \mathrm{M}$ phase.

Cell invasion inhibited by TSA of SCC-6 cells. A previous study had shown the possible function of HIF-1 $\alpha$ in the regulation of colon carcinoma cell invasion (38). To investigate TSA cancer cell invasion of SCC- 6 cells in vitro, we applied the transwell assay. After SCC-6 cells were treated with indicated concentrations of TSA, incubated in the transwell chamber for $24 \mathrm{~h}$, viola crystalline staining was used to discriminate the cells passing through the matrigel membrane which represent the invasive abilities of SCC-6 cells (Fig. 4A). As shown (Fig. 4B), with the concentrations of TSA increased, the number of SCC- 6 cells passing through the matrigel membrane significantly decreased and the inhibition rate of cell invasion increased $(12.27 \pm 1.84 \%$, $30.67 \pm 4.91 \%, 41.10 \pm 4.29 \%, \mathrm{p}<0.05,62.27 \pm 2.76 \%, 74.4 \pm 2.75 \%$ vs. $0.00 \pm 4.29 \%, \mathrm{p}<0.01)$.

Expression of HIF-1 $\alpha$ and VEGF induced by hypoxia. Hypoxia, a common microenvironment in aggressive solid tumors regulating many transcriptional factors including HIF-1 $\alpha$, which controls hypoxia-inducible angiogenic factors such as VEGF (39). As shown (Fig. 5A and C), under normoxia, control or mimic hypoxia (DFX $150 \mathrm{nmol} / \mathrm{l}$ ) groups, no significant change in HIF-1 $\alpha$ mRNA transcript was observed ( $>0.05$, Fig. 5E); basal level of VEGF mRNA expression was observed under normoxia and it became more obviously under mimic hypoxia $(\mathrm{p}<0.05$, Fig. $5 \mathrm{E})$ which increased with time and was significantly expressed at $24 \mathrm{~h}$ (Fig. 5C). Western blot assay demonstrated that hypoxia induced rapid and sustained HIF- $1 \alpha$ and VEGF protein accumulation in SCC- 6 cells in a time-dependent manner which was significant up to $24 \mathrm{~h}$ (Fig. 5B and D). These data prove the instability of HIF-1 $\alpha$ under normoxic conditions and that it stabilizes under hypoxic conditions, which suggests the hypoxic regulation of HIF-1 $\alpha$ is at the protein level. The expression of mRNA and protein levels of VEGF, a direct downstream gene of HIF-1 $\alpha$, increases significantly as the activity of HIF- $1 \alpha$ increases.

TSA inhibited hypoxia-induced accumulation of HIF-1 $\alpha$ protein and VEGF expression under hypoxic conditions. As shown (Fig. 6A), no apparent changes in HIF-1 $\alpha$ mRNA were observed in SCC-6 cells after exposed to hypoxia and TSA (800 nmol/l) for $24 \mathrm{~h}$, and different concentrations and time intervals of TSA also had no effect on HIF-1 $\alpha$ mRNA expression by RT-PCR (Fig. 6C, E and G). The results of western blotting showed a low but detectable and steady-state basal level of HIF-1 $\alpha$ protein expression under normoxia and increasing significantly under hypoxia (Figs. 5B and 6B). To investigate the temporal effects of TSA on baseline of HIF-1 $\alpha$ protein expression, we treated SCC- 6 cells with $800 \mathrm{nmol} / 1$ TSA under normoxic and found that basal level of HIF-1 $\alpha$ protein expression was reduced to
A

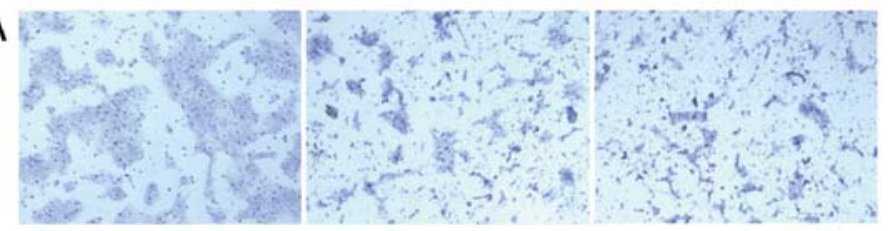

Control

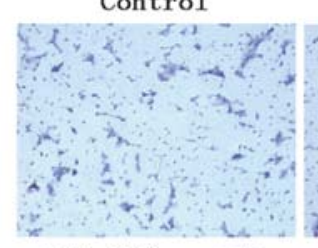

TSA 200 nmol/1
TSA $50 \mathrm{nmol} / 1$

TSA $100 \mathrm{nmol} / 1$

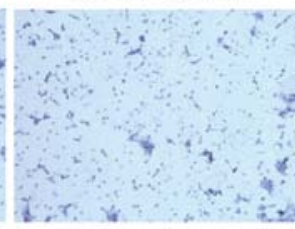

TSA $400 \mathrm{nmol} / 1$
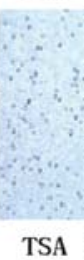

TSA $800 \mathrm{nmol} / 1$

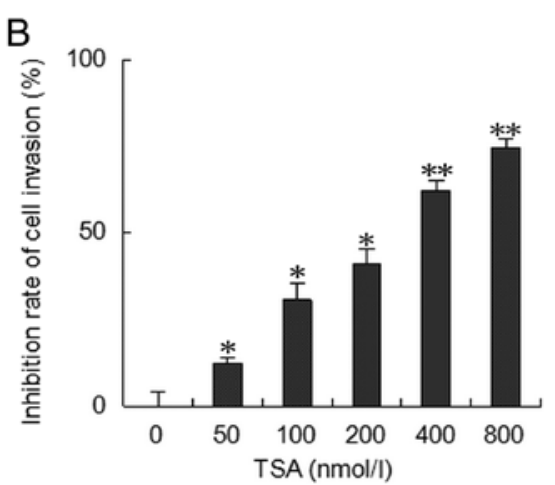

Figure 4. The effect of TSA on cell invasion of SCC- 6 cells for $24 \mathrm{~h}$ at indicated concentrations. (A) The tiny tubercle micropores on the Matrigel basement membrane of transwell chambers and the staining cells represent the invasive abilities of SCC- 6 cells (Viola crystalline staining, $\mathrm{x} 40$ ). (B) TSA inhibited cell invasion of SCC- 6 cells in a concentration-dependent manner (bars, $\pm \mathrm{SD},{ }^{*} \mathrm{p}<0.05,{ }^{* *} \mathrm{p}<0.01$, compared to control group). 
A

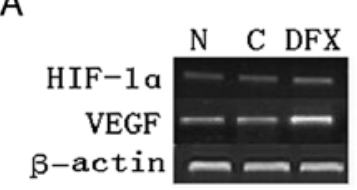

B

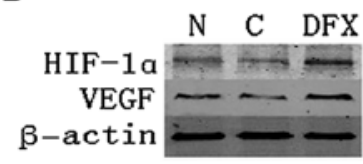

C

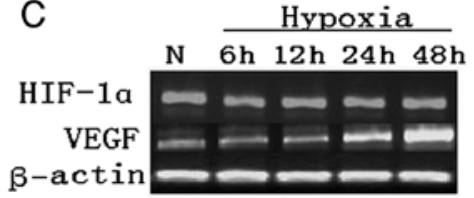

D

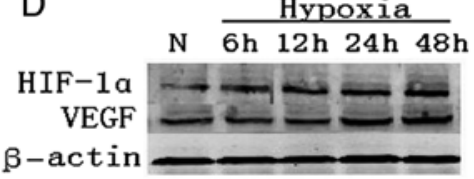

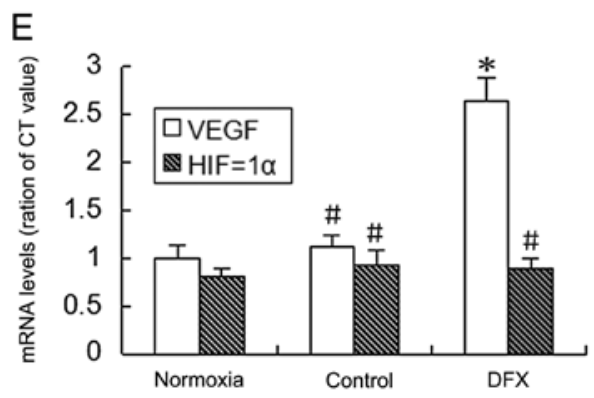

Figure 5. Mimic hypoxia induces HIF-1 $\alpha$ protein accumulation and VEGF expression. (A) The mRNA expression of HIF- $1 \alpha$ and VEGF by RT-PCR. SCC-6 cells were cultured under normoxia, control groups (normal saline water in which DFX dissolves) or DFX (150 nmol/l) for $24 \mathrm{~h}$. (B) The protein level of HIF-1 $\alpha$ and VEGF expression by western blot under normoxia, control groups or DFX ( $150 \mathrm{nmol} / \mathrm{l})$ for $24 \mathrm{~h}$. (C) The mRNA level of HIF-1 $\alpha$ and VEGF expression under mimic hypoxia in indicated time intervals. SCC-6 cells were exposed to DFX (150 nmol/l) for $6,12,24$ or $48 \mathrm{~h}$. (D) The protein level of HIF-1 $\alpha$ and VEGF expression under mimic hypoxia in indicated time intervals. (E) The quantitative analysis of HIF-1 $\alpha$ and VEGF mRNA expression under normoxia, control groups or DFX $(150 \mathrm{nmol} / \mathrm{l})$ for $24 \mathrm{~h}$, evaluated as sample threshold cycle $(\mathrm{CT})$ value divided by $\beta$-actin $\mathrm{CT}$ value (bars, $\pm \mathrm{SD}$, " $\mathrm{p}<0.05,{ }^{\#} \mathrm{p}>0.05$, compared to Normoxia groups).

low or undetectable (Fig. 6B). To explore whether TSA could also inhibit hypoxia-induced HIF-1 $\alpha$ protein expression, SCC-6 cells were treated with different concentrations and time intervals of TSA under hypoxia, the results showed that TSA inhibited hypoxia-induced HIF-1 $\alpha$ protein accumulation in a concentration and time-dependent manner (Fig. 6D and F). Markedly, this inhibitory effect was not due to a decrease in its mRNA level, suggesting that TSA inhibited hypoxia-induced HIF-1 $\alpha$ protein accumulation through a post-transcriptional mechanism.

VEGF, an immediate downstream target gene of HIF-1 $\alpha$, plays a pivotal role in tumor angiogenesis under conditions of intratumoral hypoxia $(23,40)$. To explore whether TSA could inhibit hypoxia-induced VEGF expression, we examined VEGF expression by RT-PCR and western blotting. The results showed an obvious decrease of VEGF mRNA and protein level expression after SCC- 6 cells were treated with TSA at both basal and hypoxia-induced level (Fig. 6A, B and G). To further confirm the effects of TSA on VEGF expression, SCC- 6 cells were treated with different concentrations and time intervals of TSA under hypoxia. Our results indicated that the robust increase in VEGF mRNA and protein level expression induced by hypoxia was significantly suppressed by TSA in a doseand time-dependent manner (Fig. 6C-F). Together, these data suggested that TSA inhibited hypoxia-induced angiogenesis through concurrent suppression of HIF-1 $\alpha$ and VEGF. The
A

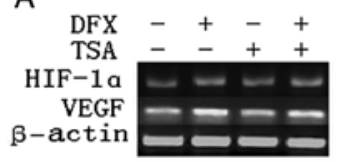

B

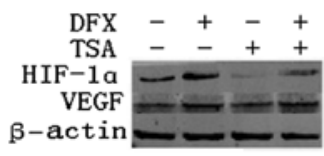

C

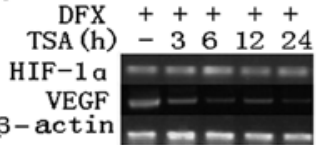

D

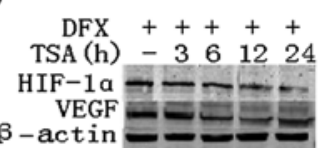

$\mathrm{F} \quad \mathrm{DFX}++++++$ TSA - 50100200400800 (nmol/1) HIF-1a

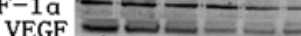

VEGF $\div-2=$

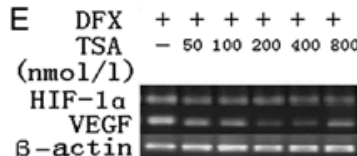

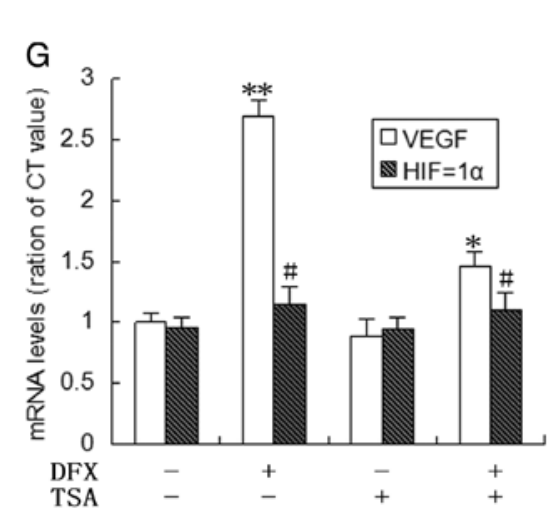

Figure 6. TSA inhibits both basal level and hypoxia induced HIF-1 $\alpha$ protein accumulation and VEGF expression under hypoxic conditions. (A) The effect of TSA on mRNA level of HIF- $1 \alpha$ and VEGF expression by RT-PCR. SCC-6 cells were cultured under normoxia, DFX $(150 \mathrm{nmol} / \mathrm{l})$, TSA $(800 \mathrm{nmol} / \mathrm{l})$ or DFX $(150 \mathrm{nmol} / \mathrm{l})$ and TSA $(800 \mathrm{nmol} / \mathrm{l})$ for $12 \mathrm{~h}$, respectively. (B) The effect of TSA on protein level of HIF-1 $\alpha$ and VEGF expression by western blotting. (C) The effect of TSA at indicated time intervals on mRNA level of HIF-1 $\alpha$ and VEGF expression under hypoxic conditions. SCC- 6 cells were exposed to DFX $(150 \mathrm{nmol} / \mathrm{l})$ for $24 \mathrm{~h}$, then treated with TSA $(800 \mathrm{nmol} / \mathrm{l})$ for $3,6,12,24 \mathrm{~h}$. (D) The effect of TSA at indicated time intervals on protein level of HIF-1 $\alpha$ and VEGF expression under hypoxic conditions. (E) Indicated concentrations of TSA on mRNA level of HIF-1 $\alpha$ and VEGF expression under hypoxic conditions. SCC-6 cells were exposed to DFX $(150 \mathrm{nmol} / \mathrm{l})$ for $24 \mathrm{~h}$, then treated with TSA at $50,100,200,400,800 \mathrm{nmol} / 1$ for $12 \mathrm{~h}$. (F) Indicated concentrations of TSA on protein level of HIF-1 $\alpha$ and VEGF expression under hypoxic conditions. (G) The quantitative analysis of HIF-1 $\alpha$ and VEGF mRNA expression under normoxia, DFX (150 nmol/l), TSA ( $800 \mathrm{nmol} / \mathrm{l})$ or DFX $(150 \mathrm{nmol} / \mathrm{l})$ and TSA $(800 \mathrm{nmol} / \mathrm{l})$ for 24 or $12 \mathrm{~h}$, respectively, evaluated as sample threshold cycle (CT) value divided by $\beta$-actin CT value (bars, $\pm \mathrm{SD},{ }^{*} \mathrm{p}<0.05,{ }^{* *} \mathrm{p}<0.01$, ${ }^{\#} \mathrm{p}>0.05$, DFX compared to Normoxia groups, DFX and TSA compared to DFX groups).

viability of SCC-6 cells showed no apparent changes in cell morphology or toxicity at the above concentrations of TSA for $12 \mathrm{~h}$ (Fig. 1), indicating that this inhibitory effect by TSA was not ascribed to nonspecific tumor cell toxicity.

\section{Discussion}

Histone deacetylation and acetylation is considered as a key regulatory mechanism of gene transcription. Histone deacetylases (HDACs) act to oppose the activity of histone 
acetyltransferases (HATs). The dysfunction of HDACs and HATs may lead to tumorigenesis which has been confirmed in leukemia (41). Past research demonstrated that HDAC inhibitor exerts anticancer activity via suppression of HDAC activity, induction of histone acetylation and regulation of gene transcription $(42,43)$. Recently, specific HDAC inhibitors such as LAQ824, FK228, sodium butyrate, resveratrol and trichostatin A have been reported to inhibit tumor growth, survival, metastasis and downregulate HIF-1 $\alpha$ stability in many cancer cell lines (44-48). HIF-1 $\alpha$, regulated by hypoxia, transactives many target genes encoding proteins related to tumor angiogenesis, regulation of blood vessel tone, and vascular remodelling by HIF- $1 \alpha$ mediated overexpression of VEGF and NO; cell proliferation and viability by IGF-2; erythropoiesis and iron metabolism by EPO; glucose transport and glycolysis by GLU-1,3, which makes HIF-1 $\alpha$ a key transcriptional factor in tumor cell survival (13).

In this study, we adopted a potent HDAC inhibitor, trichostatin A (TSA), with anticancer activity. It was first reported to induce cell differentiation in mice leukemia cells by Yoashi in 1987 (49), demonstrated to inhibit tumor cell proliferation, block cell cycle, induce cell apoptosis and differentiation, block tumor angiogenesis in vitro and in vivo, via upregulating p53 and VHL expression and downregulating HIF-1 $\alpha$ and VEGF $(12,50)$. TSA significantly inhibited cell proliferation of SCC-6 cells in vitro in a dose- and time-dependent manner (Fig. 1) which was partially related to TSA-induced cell apoptosis with the same dose- and time-dependent manner (Fig. 2). HIF-1 $\alpha$ was the key regulator to cellular adaptation under hypoxia, at the same time, endoplasmic reticulum (ER) stress could be induced and resulted in inhibition of protein translation, which could induce the cells to enter the cell cycle, leading to mitogenic responses. Therefore, the proliferation of SCC- 6 cells may be an integrated stress response involving an ER-generated signal and the cellular adaptation to hypoxia (51).

HIF-1 $\alpha$ regulates target genes directly or indirectly relating to cell apoptosis, some of which play a dual role in regulating apoptosis of tumor cells, which makes HIF-1 $\alpha$ both anti-apoptotic and pro-apoptotic. It is the oxygen tension that considered to determine whether HIF-1 $\alpha$ function as antiapoptotic or pro-apoptotic. Blagosklonny et al reported that the stabilization of $\mathrm{p} 53$ protein depend on HIF-1 $\alpha$, resulting in the induction of apoptosis under hypoxia (52). However, another study showed that HIF-1 $\alpha$ might have a protective role in limiting hypoxia-induced apoptosis via suppression of caspase-3 activity (53). There is a cell cycle specificity in some type of cell apoptosis, acting as different inducements in cell apoptosis at different cell cycle phases. Cell apoptosis occurs after cell cycle blockade at a certain phase $(54,55)$. To investigate whether the TSA-induced cell apoptosis of SCC-6 cells is cell cycle specific, we analyzed cell cycles of SCC-6 cells after treated with TSA by FCM. The percentage of cells at $\mathrm{G}_{2} / \mathrm{M}$ phase increased and cells at $\mathrm{G}_{0} / \mathrm{G}_{1}$ phase decreased as the concentration of TSA increased, which agreed with the change of cell apoptosis rate (Fig. 3). Thus, we presume the TSA-induced cell apoptosis of SCC- 6 cells is relevant to its cell cycle blockade at $\mathrm{G}_{2} / \mathrm{M}$ phase.

Cell invasion, involved in tumor metastasis and progression, is known to be upregulated by hypoxia, through hypoxiainduced expression of matrix metalloproteases (MMPs) and inhibition of E-cadherin and $\beta$-catenin. The present study analyzed the effect on cell invasion of SCC- 6 cells by TSA applying a transwell assay in vitro. Results showed that after treated with different concentrations of TSA, cell numbers that passed through the extracellular matrices (ECM) reduced significantly and inversely correlated with the TSA concentrations (Fig. 4). Thus, TSA inhibits cell invasion of SCC-6 cells in vitro in a dose-dependent manner.

HIF-1 $\alpha$ is hydroxylated, acetylated and bound by the von Hipple-Lindau (pVHL) ubiquitin E3 ligase complex under normoxia, leading to HIF-1 $\alpha$ polyubiquitination and proteosomal degradation. In contrast, under hypoxia, HIF-1 $\alpha$ hydroxylation and acetylation are surppressed by low oxygen tension, leading to stabilization of HIF-1 $\alpha$, which translocates to the nucleus to bind HIF-1 $\beta$ and recruit $\mathrm{CBP} / \mathrm{p} 300$ resulting in gene transcription. Hypoxia also induces HDACs expression which deacetylates HIF-1 $\alpha$ to increase HIF-1 $\alpha$ transcriptional activity. Thus, HDAC inhibitor reverses the activity of HDACs resulting in the degradation of HIF-1 $\alpha(6,28,44,46)$. Our study demonstrated that TSA inhibited both basal level and hypoxiainduced HIF-1 $\alpha$ protein accumulation and VEGF mRNA and protein expression under hypoxia (Figs. 5 and 6). This significant inhibitory effect of VEGF may play a direct and critical role in the inhibition of angiogenesis under hypoxic conditions. However, to investigate whether the anti-angiogenic activity of TSA is the hypoxia-specific regulated mechanism, an in vivo tumor generation experiments with SCC- 6 cells is needed. Only when the results of in vivo experiments are in accordance with the outcome of the present in vitro experiments can we presume that the functional HIF- $1 \alpha$ and its target, VEGF, play critical roles in tumor cells in the process of hypoxia-induced tumor angiogenesis.

In conclusion, our present study demonstrates that TSA, a HDAC inhibitor, function as a powerful anticancer agent in vitro through its potent inhibition of HIF-1 $\alpha$ and its downstream target gene, VEGF, under hypoxia, a common characteristic of most solid cancers. We suggest that TSA can be further investigated as a novel anticancer agent targeting tumor angiogenesis via inhibition of HIF-1 $\alpha$ activity and VEGF expression.

\section{Acknowledgements}

Our study was supported by the Project of Science and Technology Talents of Shanghai, Science and Technology Commission of Shanghai Municipality (Grant No. 09QA1406400). We also thank Wang Kai and Gao Yin for their excellent technical and theoretical assistance.

\section{References}

1. Guillemin K and Krasnow MA: The hypoxic response: huffing and HIFing. Cell 89: 9-12, 1997.

2. Ryan HE, Lo J and Johnson RS: HIF-1 $\alpha$ is required for solid tumor formation and embryonic vascularization. EMBO J 17: 3005-3015, 1998

3. Kim KW, Bae SK, Lee OH, et al: Insulin-like growth factor II induced by hypoxia may contribute to angiogenesis of human hepatocellular carcinoma. Cancer Res 58: 348-351, 1998.

4. Höckel M, Schlenger K, Mitze M, et al: Hypoxia and radiation response in human tumors. Semin Radiat Oncol 6: 3-9, 1996.

5. Höckel $\mathrm{M}$ and Vaupel P: Tumor hypoxia: definitions and current clinical, biologic, and molecular aspects. J Natl Cancer Inst 93: 266-276, 2001 . 
6. Ellis L, Hammers H and Pill R: Targeting tumor angiogenesis with histone deacetylase inhibitors. Cancer Lett 280: 145-153, 2009.

7. Wenger RH and Gassman M: Oxygen and the hypoxia-inducible factor-1. J Biol Chem 378: 609-616, 1997.

8. Nor JE, Christensen J, Mooney DJ, et al: Vascular endothelia growth factor (VEGF)-mediated angiogenesis is associated with enhanced endothelial cell survival and induction of Bcl-2 expression. Am J Pathol 154: 375-384, 1999.

9. Gupta K, Kshirsagar S, Li W, et al: VEGF prevents apoptosis of human microvascular endothelial cells via opposing effects on MAPK/ERK and SAPK/JNK signaling. Exp Cell Res 247: 495-504, 1999.

10. Baek JH, Jang JE, Kang CM, et al: Hypoxia-induced VEGF enhances tumor survivability via suppression of serum deprivationinduced apoptosis. Oncogene 19: 4621-4631, 2000.

11. Waltenberger J, Mayr U, Pentz S, et al: Functional upregulation of the vascular endothelial growth factor receptor KDR by hypoxia. Circulation 94: 1647-1654, 1996.

12. Myoung SK, Kwon HJ, Lee YM, et al: Histone deacetylases induce angiogenesis by negative regulation of tumor suppressor genes. Nat Med 7: 437-443, 2001.

13. Semenza GL: Hypoxia-inducible factor-1: master regulator of $\mathrm{O}_{2}$ homeostasis. Curr Opin Genet Dev 8: 588-594, 1998.

14. Kallio PJ, Pongratz I, Gradin K, et al: Activation of hypoxiainducible factor 1alpha: posttranscriptional regulation and conformational change by recruitment of the Arnt transcription factor. Proc Natl Acad Sci USA 94: 5667-5672, 1997.

15. Epstein AC, Gleadle JM, McNeill LA, et al: Elegans EGL-9 and mammalian homologs define a family of dioxygenases that regulate HIF by prolyl hydroxylation. Cell 107: 43-54, 2001.

16. Ivan M, Konda K, Yang H, et al: HIF-1 $\alpha$ targeted for VHL-mediated destruction by proline hydroxylation: implications for $\mathrm{O}_{2}$ sensing. Science 292: 464-468, 2001.

17. Jaakkola P, Mole DR, Tian YM, et al: Targeting of HIF-1 $\alpha$ to the von Hippel-Lindau ubiquitilation complex by $\mathrm{O}_{2}$-regulated prolyl hydroxylation. Science 292: 468-472, 2001.

18. Salceda $S$ and Caro J: Hypoxia-inducible factor- $1 \alpha$ protein is rapidly degraded by the ubiquitin-proteosome system under normoxic conditions: its stabilization by hypoxia depends on redox-induced changes. J Biol Chem 272: 22642-22647, 1997.

19. Huang LE, Gu J, Schau M, et al: Regulation of hypoxia-inducible factor $1 \alpha$ is mediated by an $\mathrm{O}_{2}$-dependent degradation domain via the ubiquitin-proteasome pathway. Proc Natl Acad Sci USA 95: 7987-7992, 1998.

20. Maxwell PH, Wiesener MS, Chang GW, et al: The tumor suppressor protein VHL targets hypoxia-inducible factors for oxygen-dependent proteolysis. Nature 399: 271-275, 1999.

21. Ema M, Hirota K, Mimura J, et al: Molecular mechanisms of transcription activation by HLF and HIF 1alpha in response to hypoxia: their stabilization and redox signal-induced interaction with CBP/p300. EMBO J 18: 1905-1914, 1999.

22. Huang LE, Arany Z, Livingston DM and Bunn HF: Activation of hypoxia-inducible transcription factor depends primarily upon redox-sensitive stabilization of its alpha subunit. J Biol Chem 271: 32253-32259, 1996.

23. Semenza GL: Targeting HIF-1 for cancer therapy. Nat Rev Cancer 3: 721-732, 1996.

24. Grunstein M: Histone acetylation in chromatin structure and transcription. Nature 389: 349-352, 1997.

25. Kawaguchi Y, Kovacs JJ, McLaurin A, et al: The deacetylase HDAC6 regulates aggresome formation and cell viability in response to misfolded protein stress. Cell 115: 727-738, 2003

26. Hubbert C, Guardiola A, Shao R, et al: HDAC6 is a microtubuleassociated deacetylase. Nature 417: 455-458, 2002

27. Matsuyama A, Shimazu T, Sumida Y, et al: In vivo destabilization of dynamic microtubules by HDAC6-mediated deacetylation. EMBO J 21: 6820-6831, 2002

28. Kouraklis $\mathrm{G}$ and Theocharis S: Histone deacetylase inhibitors and anticancer therapy. Curr Med Chem Anti-Cancer Agents 2: 477-484, 2002

29. Rosato RR and Grant S: Histone deacetylase inhibitors in cancer therapy. Cancer Biol Ther 2: 30-37, 2003.

30. Kosugi H, Towatari M, Hatano S, et al: Histone deacetylase inhibitors are the potent inducer/enhancer of differentiation in acute myeloid leukemia: a new approach to anti-leukemia therapy. Leukemia 13: 1316-1324, 1999.

31. Balanos GM, Dorrington KL and Robbins PA: Desferrioxamine elevates pulmonary vascular resistance in humans: potential for involvement of HIF-1. J Appl Physiol 92: 2501-2507, 2002.
32. Ardyanto TD, Osaki M, Tokuyasu N, et al: $\mathrm{CoCl}_{2}$-induced HIF- $1 \alpha$ expression correlates with proliferation and apoptosis in MKN-1 cells: a possible role for the PI3K/Akt pathway. Int J Oncol 29: 549-555, 2006

33. Abasolo I, Wang Z, Montuenga LM, et al: Adrenomedullin inhibits prostate cancer cell proliferation through a cAMP independent autocrine mechanism. Biochem Biophys Res Commun 322: 878-886, 2004

34. Martin SJ, Reutelingsperger $\mathrm{CP}, \mathrm{McGahon} \mathrm{AJ}$, et al: Early redistribution of plasma membrane phosphatidylserine is a general feature of apoptosis regardless of the initiating stimulus: inhibition by overexpression of Bcl-2 and Abl. J Exp Med 182: 1545-1556, 1995

35. Leong DT, Gupta A, Bai HF, et al: Absolute quantification of gene expression in biomaterial research using real-time PCR Biomaterials 28: 203-210, 2007.

36. Lee SW, Han SI, Kim HH, et al: TAK1-dependent activation of AP-1 and c-Jun N-terminal kinase by receptor activator of NF-jB, J Biochem Mol Biol 35: 371-376, 2002.

37. Chun YS, Choi E, Kim GT, et al: Cadmium blocks hypoxiainducible factor (HIF)-1-mediated response to hypoxia by stimulating the proteasome-dependent degradation of HIF-1 $\alpha$. Eur J Biochem 267: 4198-4204, 2000.

38. Krishnamachary B, Berg-Dixon S, Kelly B, et al: Regulation of colon carcinoma cell invasion by hypoxia-inducible factor-1. Cancer Res 63: 1138-1143, 2003.

39. Carmeliet P, Dor Y, Herbert JM, et al: Role of HIF-1 $\alpha$ in hypoxiamediated apoptosis, cell proliferation and tumour angiogenesis. Nature 394: 485-490, 1998

40. Shweiki D, Itin A, Soffer D, et al: Vascular endothelial growth factor induced by hypoxia may mediate hypoxia-initiated angiogenesis. Nature 359: 843-845, 1992.

41. Fenrick R and Hiebert SW: Role of histone deacetylases in acute leukemia. J Cell Biochem (Suppl) 30-31: 194-202, 1998.

42. Kung AL, Wang S, Klco JM, et al: Suppression of tumor growth through disruption of hypoxia-inducible transcription. Nat Med 6: 1335-1340, 2000.

43. Semenza GL: Hypoxia, clonal selection, and the role of HIF-1 in tumor progression. Crit Rev Biochem Mol Biol 35: 71-103, 2000.

44. Kwon HJ, Kim MS, Kim MJ, et al: Histone deacetylase inhibitor FK228 inhibits tumor angiogenesis. Int J Cancer 97: 290-296, 2002.

45. Vigushin DM, Ali S, Pace PE, et al: Trichostatin A is a histone deacetylase inhibitor with potent antitumor activity against breast cancer in vivo. Clin Cancer Res 7: 971-976, 2001

46. Lee YM, Kim SH, Jin Son M, et al: Inhibition of hypoxiainduced angiogenesis by FK228, a specific histone deacetylase inhibitor, via suppression of HIF-1 $\alpha$ activity. Biochem Biophys Res Commun 300: 241-624, 2003.

47. Liu LT, Chang HC, Chiang LC, et al: Histone deacetylase inhibitor up-regulates RECK to inhibit MMP-2 activation and cancer cell invasion. Cancer Res 63: 3069-3072, 2003.

48. Zhang QZ, Tang XD, Liu QY, et al: Resveratrol inhibits hypoxiainduced accumulation of hypoxia-inducible factor-1A and VEGF expression in human tongue squamous cell carcinoma and hepatoma cells. Mol Cancer Ther 4: 1465-1473, 2005.

49. Yoshida M, Kijima M, Akita M, et al: Potent and specific inhibition of mammalian histone deacetylase both in vivo and in vitro by trichostatin A. J Biol Chem 265: 17174-17179, 1990.

50. Xiao H, Hasegawa T and Isobe K: p300 collaborates with Sp1 and $\mathrm{Sp} 3$ in $\mathrm{p} 21$ (waf 1/cip1) promoter activation induced by histone deacetylase inhibitor. J Biol Chem 275: 1371-1376, 2000.

51. Song Y, Wang WX, Qu X, et al: Effects of hypoxia inducible factor- $1 \alpha$ on the growth and adhesion in tongue squamous cell carcinoma cells. Indian J Med Res 129: 154-163, 2009.

52. Blagosklonny MV, An WG, Romanova LY, et al: p53 inhibits hypoxia-inducible factor-stimulated transcription. J Biol Chem 273: 11995-11998, 1998

53. Akakura N, Kobayashi M, Horiuchi I, et al: Constitutive expression of hypoxia-inducible factor-1alpha renders pancreatic cancer cells resistant to apoptosis induced by hypoxia and nutrient deprivation. Cancer Res 61: 6548-6554, 2001.

54. Strait KA, Dabbas B, Hammond EH, et al: Cell cycle blockade and differentiation of ovarian cancer cells by the histone deacetylase inhibitor trichostatin A are associated with changes in $\mathrm{p} 21, \mathrm{Rb}$, and Id proteins. Mol Cancer Ther 1: 1181-1190, 2002.

55. Kim YB, Ki SW, Yoshida M, et al: Mechanism of cell cycle arrest caused by histone deacetylase inhibitors in human carcinoma cells. J Antibiot 53: 1191-1200, 2000. 